\title{
O CÓDIGO DE PROCESSO CRIMINAL DE PRIMEIRA INSTÂNCIA: DO CONTEXTO AO TEXTO IMPERIAL E AS INFLUÊNCIAS ATUAIS
}

Érica Babini Lapa do Amaral Machado ${ }^{1}$

\section{Resumo}

O texto problematiza as raízes do modelo processual brasileiro no Código de Processo Criminal de primeira instancia, primeiro documento processual do Império, e suas influências no atual modelo brasileiro. Para a abordagem, vale-se da história crítica do Direito, por meio de revisão bibliográfica, a partir da contextualização do cenário político do surgimento do documento e suas implicações culturais para os dias atuais, visando, com isso, a identificação desses resquícios para a construção de estratégias de superação do ranço inquisitivo no sentido do respeito às garantias fundamentais.

Palavras-chave: Modelos Processuais; História Crítica do Direito; Código de Processo Criminal de Primeira Instancia.

\section{A ADMINISTRAÇÃO DA JUSTIÇA E O PROCESSO PENAL BRASILEIRO: FORMAS DE TRANSIÇÃO DEMOCRÁTICA INACABADAS}

Juarez Tavares² aponta algo que parece simples, apesar de não sê-lo. Afirma que no modelo constitucional e democrático optado pela sociedade brasileira, com a Constituição de 1988, a garantia e o exercício da liberdade individual não precisam quaisquer legitimação, face a sua evidência; o que já não é o mesmo com o poder punitivo do Estado que precisa se justificar.

\footnotetext{
${ }^{1}$ Doutora em Direito pela Universidade Federal de Pernambuco. Professora da Universidade Católica de Pernambuco UNICAP.E-mail: ericababini@hotmail.com

${ }^{2}$ TAVARES, Juarez. Teoria do Injusto Penal. 3 ed. Belo horizonte: Del Rey, 2003.
} 
Isto é, no modelo do Estado Democrático de Direito, é absolutamente necessário que as regras do jogo sejam observadas a partir da Constituição, devendo-se empreender luta para superar a crença de que o processo penal está a serviço da segurança pública. Nas lições de Geraldo Prado, o processo penal é instrumental e está à serviço de uma única finalidade: realização de um projeto democrático, e não à serviço de uma pretensão acusatória, o que significa uma máxima eficiência dos direitos e garantias fundamentais ${ }^{3}$, funcionando como instrumento de efetivação das garantias constitucionais ${ }^{4}$.

Nesse aspecto, o processo penal é o limite da atividade jurisdicional, as regras do permitido e proibido no que diz respeito ao jus puniendi do Estado, regras essas que nem o legislador, tampouco o operador do direito, poderão fugir.

Visto como único e necessário instrumento para apuração do delito imputado ao agente, o processo é regido por ditames e garantias específicas que visam assegurar a igualdade das partes, colocando o acusado no mesmo patamar do órgão de perseguição penal. Tais garantias, inerentes ao Estado Democrático de Direito, foram sendo acrescentadas nas cartas legislativas ao longo dos anos, aprimorando o direito processual para fazer dele um instrumento de justiça.

Nesse sentido, a submissão do cidadão ao poder estatal, no processo penal, reclama o estabelecimento de regras e princípios que regulamentem e direcionem a conflitante relação entre as partes na jurisdição penal. A polarização entre o resguardo ao jus libertatis e a necessidade de punição decorrente de violação da norma penal exige um atento e detalhado processo de aferição de culpa. Tal processo, por sua vez, deve revestir-se de meios eficazes para suprir, ao máximo, a desigualdade de forças entre o acusado e Estado. Nesse diapasão, as garantias e limites processuais nada mais são do que a contenção da persecução penal, a redoma de proteção do réu, a inibição do arbítrio, o resguardo da liberdade individual.

Os direitos humanos são a barreira nesse sentido, pois de um lado, como proteção institucionalizada dos direitos da pessoa humana contra os excessos do poder estatal e, de outro, como regras para estabelecer condições de vida e desenvolvimento na personalidade humana 5 .

No entanto, não é possível afirmar a concretização democrática no país, nem mesmo após a Constituição Federal de 1988, pois, vive-se nos dias atuais uma transição inacabada, a qual é marcada em episódios de violências, com proporções internacionais. Aliás, no mesmo período da superação dos arbítrios

\footnotetext{
${ }^{3}$ PRADO, Geraldo. A transição democrática no Brasil e o Sistema de Justiça Criminal. Palestra proferida no Ciclo de Conferências organizado pela Faculdade de Direito, pelo Programa de Pós Doutoramento em Democracia e Direitos Humanos e pelo Centro de Estudos Interdisciplinares do Século 20 da Universidade de Coimbra em 06 de novembro de 2012, no âmbito do módulo de Direito Penal coordenado pela prof. Cláudia Santos.

${ }^{4}$ LOPES JR., Aury. Direito Processual Penal. 10a Ed. São Paulo: Saraiva, 2013, p. 59.

${ }^{5}$ BALDAN, Édson Luis. Direitos fundamentais na Constituição Federal. Estado democrático de direito e os fins do processo penal. In: SILVA, Marco Antônio Marques. Tratado Temático de Processo Penal. São Paulo: Juarez de Oliveira, 2002. p. 110-134.
} 
militares, conviveu-se (na década de 90) com o massacre do Carandiru, da Candelária, de Vigário Geral, de Corumbiara e El Dourado dos Carajás, todos eles, emblemáticos, para não mencionar os extermínios diários que têm em comum a presença de agentes do Estado, supostamente encarregados de fazer cumprir os direitos fundamentais, emblematicamente postos no núcleo intangível do art. $5^{\circ}$ (dentre outros) ${ }^{6}$.

As consequências desse cenário são sensação de insegurança, crescimento do medo social, pânico da vida coletiva, autocolocação na condição de vítima. Daí então, o tema segurança pública tornou-se lugar comum, deixando de fazer parte dos estudos técnicos dos experts para pousar nas mais triviais discussões do senso comum ${ }^{7}$.

Isto é, não se pode perder de vista que, analisar as influências das tradições e os rumos da sociedade brasileira, do ponto de vista histórico, implica permanente revisão dos conteúdos, sobretudo quando "há um interesse atualizado pelas interpretações que o Brasil recebeu e recebe, e uma nova curiosidade acerca destes 'Brasis, desenhados, projetados e imaginados por tantos pensadores locais e estrangeiros".

Apesar de tal observação, não se pretende aqui realizar a construção das ideias (evitando reviver Hamurábi ${ }^{9}$ ), mas tão somente perceber como traços da sociabilidade brasileira influenciam decisões e práticas político-criminais. Para tanto é indispensável o recurso do pensamento social brasileiro, de modo que é preciso ir ao passado com perguntas do presente buscando significados e sentidos da formação social.

Aliás, no Brasil, uma sociedade onde nunca houve a universalização da escola, onde os aparelhos da justiça penal sempre foram brutais e muito pouco eficazes, para dizer o mínimo, e onde, finalmente, uma imensa força de trabalho, miserável e informal, não possibilitou - e possibilita cada vez menos, em um planeta dominado pela revolução tecnológica e pela globalização - a constituição de um mundo do trabalho hegemonicamente enquadrado pelo dispositivo da fábrica ${ }^{10}$.

Por outro lado, o legado da violência, realizada explicita ou clandestinamente, seja pelo Estado seja pela população não pode ser escamoteado por eufemismo de linguagem. Não pode ser indizível numa realidade onde há muito boa aceitação dos métodos de tortura do Capitão Nascimento, personagem do filme Tropa de Elite "filme que virou mais do que fenômeno cultural, um evento sociológico - mostra a que níveis de degradação pode

\footnotetext{
${ }^{6}$ BELLI, Benoni. Tolerância Zero e democracia no Brasil: visões da segurança pública na década de 90. São Paulo: Perspectiva, 2004.

${ }^{7}$ GARLAND, David. A cultura do controle. Crime e ordem social na sociedade contemporânea. Rio de Janeiro: Revan, 2008.

${ }^{8}$ SCHWARCZ, Lilia Moritz; BOTELHO, André. Um enigma chamado Brasil: 29 intérpretes e um país. São Paulo: Companhia das Letras, 2009, p. 11.

${ }^{9}$ OLIVEIRA, Luciano. A pesquisa sócio-juridica na pós-graduação em Direito. Sua Excelência o Comissário e outros ensaios de Sociologia jurídica. Rio de Janeiro: Letra Legal, 2004.

${ }^{10}$ OLIVEIRA, Luciano. Relendo "Vigiar e Punir", Dilemas: Revista de Estudos de Conflito e Controle Social - Vol. 4 - n 2, - pp. 309-338, abr/mai/jun, 2011, p. 334
} 
chegara sensibilidade de uma população acuada pelo medo"11.

Considerando "as estruturas sociais brasileiras que, fundadas na época da Colônia, atravessaram incólumes o longo do Império e as várias repúblicas que temos tido. O modo de produção escravagista, vigente durante quatro séculos, sucedeu um capitalismo sem preocupações sociais e uma democracia de poucos cidadãos" o que se pode ter como hipótese é que "a pobreza, a miséria e a subserviência das massas asseguram a continuidade de uma estrutura que permaneceu subterrânea".

Os avanços democráticos de eleições livres, entretanto, não foram suficientes para conter o sentimento de medo e insegurança ante o crescimento da criminalidade ${ }^{12}$, pois diante de estatísticas criminais oficiais que demonstravam o crescimento das modalidades de violência individual urbana - homicídio, roubo à mão armada, sequestros e estupros - só cabia à população a exigência de políticas de segurança pública.

$\mathrm{Na}$ verdade, como transitar de um estado de exceção (histórico) - de pura violência - para um Estado Democrático de Direito, caracterizado pelo uso de uma violência contida e limitada por um poder legítimo? Uma pergunta que deve ser feita na medida em que o trânsito para o regime democrático não leva consigo todos os elementos da democracia. A prova disto é que na realidade brasileira há uma permanência autoritária dentro do novo regime democrático, que acabou por constituir uma cultura política do controle, que combina os paradigmas autoritário e democrático, de forma a não sermos mais capazes de distingui-los.

De antemão, cumpre esclarecer que o autoritarismo pode ser simbolicamente representado por diversas formas de violências, onde uma, bastante experimentada pelos brasileiros, pode sintetizar sua face: a tortura. É triste admitir, ainda no presente, os signos das violências de forma disfarçada, mas, principalmente, em "microrrelações de autoritarismo imersas no cotidiano, que perpetuam as relações sistemáticas aos direitos fundamentais de diversas minorias".

Em verdade, as ações violentas precedem ou coexistem com ideias autoritárias, sua larga vigência num país periférico como o Brasil denuncia seu enraizamento, tanto que Bóris Fausto ${ }^{13}$ radica seu surgimento na década de 1920, "na vigência de um regime oligárquico-liberal, que ganhou forma com a Proclamação da República (1889)”.

Enfim, a cultura da política no Brasil, de alguma maneira, incorporou a violência como elemento cotidiano da sua vida. Mais ainda, a inteligência brasileira operou no sentido de fundamentar nosso autoritarismo precedente, como uma forma, também, de nos aliviar do peso de uma consciência pregressa e pacificá-la para

\footnotetext{
${ }^{11}$ OLIVEIRA, Luciano. Do nunca mais ao eterno retorno. Uma reflexão sobre a tortura. São Paulo: brasiliense, 2009, p. 14

${ }^{12}$ As estatísticas criminais são matéria controvertida. No entanto, diversas análises apontavam para uma tendência mundial de crescimento de crimes relativos à integridade física dos indivíduos, de modo ser esta uma afirmativa relativamente consensual na sociologia criminal. ADORNO, Sérgio. Insegurança versus direitos humanos. Entre a lei e a ordem. Tempo Social; Rev. Scoiol. USP, São Paulo, 11 (2): 129-153, out. 1999.
} 
autoritarismos futuros. Inclusive, isto vem sendo de grande valia, vide o fato que na história republicana do Brasil passamos mais tempo em regimes autoritários que democráticos. Afinal, "poucos que controlam tudo precisam desses intelectuais e especialistas do mesmo modo que os coronéis de antigamente necessitavam do seu pequeno exército de cangaceiros". O dinheiro compra uma "ciência para os seus interesses" ${ }^{14}$.

Ante a todos esses elementos, no âmbito processual penal, que reflete exatamente o exercício do poder punitivo, importa questionar sobre as raízes da consolidação dos modelos processuais penais nas legislações. É neste sentido que o objetivo, portanto, é identificar elementos históricos oriundos do Código de Processo Criminal do Império, para se ponderar sobre suas raízes e, a partir de então, repensar alternativas para uma reconstrução cultural voltada à implementação da democratização do processo penal, entendida esta como a consagração de direitos fundamentais.

Enfim, este texto, pautado na perspectiva do marco teórico da teoria crítica do direito e da nova história, se afasta da montagem excludente da lógica colonialista-privilegiadora da história tradicional (linear) para aproximar-se de uma vertente emancipadora, restauradora das especificidades locais latino-americanas, visando assim, uma reflexão sobre o oficialmente consagrado (discurso) ${ }^{15}$.

A teoria crítica da história pretende repensar formas sacralizadas da cultura jurídica para, a partir do autoconhecimento dos institutos, seja possível transformar a realidade social. Trata-se da recusa de uma historicidade identificada com o discurso dominante para valer-se da história militante, criadora e focada na transformação do mundo.

Enfim, é uma forma de priorizar a dimensão epistemológica e a função político ideológica dos conceitos ("uma tentativa de superação metodológica representada pelo historicismo legal de cunho formalista, erudito e elitista") ${ }^{16}$, pautando-se, assim numa forma crítica de abordagem.

Nesse sentido, evidencia-se a não pretensão de traduzir a história geral e completa, tampouco rigorosamente neutra e sistemática sob os cânones científicos, mas tão somente compreender os efeitos daquela cultura na formação da prática social, jurídico-discursiva atual; tudo justificado pelo caráter mutável, imperfeito e relativo da experiência humana permitindo, portanto, diversas interpretações.

Portanto, o entrelaçamento histórico em torno dos conceitos não será manejado como temporalizações, e sim como artífice de interpretação política, a fim de perceber as interseções das aspirações ideológicas postadas pelo período sobre o sistema de justiça criminal. Afinal, não se pode perder de vista que "os conteúdos históricos podem permitir descobrir a clivagem dos enfrentamentos e das lutas que as ordenações funcionais ou as

\footnotetext{
${ }^{13}$ FAUSTO, Boris. O pensamento nacionalista autoritário (1920-1940). Rio de Janeiro: Jorge Zahar, 2001, p. 14.

${ }^{14}$ SOUZA, Jessé. A tolice da inteligência brasileira: ou como o país se deixa manipular pela elite. São Paulo: LeYa, 2015, p. 10.

${ }^{15}$ WOLKMER, Antonio Carlos. Introdução ao pensamento jurídico crítico. São Paulo: Acadêmica, 1995.
} 
organizações sistemáticas tiveram como objetivo, justamente mascarar” ${ }^{17}$.

\section{CONTEXTO POLÍTICO E A LEGISLAÇÃO PROCESSUAL PENAL DO IMPÉRIO}

As formas históricas do processo penal são pedagogicamente apresentadas entre sistema inquisitivo, acusatório. Era o modelo predominante no continente europeu, sendo utilizado como instrumento de consolidação do absolutismo dinástico imperante nas monarquias europeias; a exemplo da Constitucio Criminalis Carolina.

O modelo acusatório que impera na estrutura constitucional, tem que a gestão da prova é o critério que demarca a diferença para o processo inquisitivo. No inquisitório, o juiz carrega poderes de iniciativa e produção probatória, enquanto que no acusatório esse poder é das partes. No modelo inquisitivo, o juiz deixa de ser expectar para ser protagonista e o processo é sigiloso, cabendo a ele buscar a verdade dos fatos, razão pela qual o resultado é colonizado pela resposta satisfatória, afinal, ele tem que justificar sua atuação.

O manual dos inquisidores do catalão Nicolau Eymerich relata o modelo inquisitório do direito canônico que influenciou definitivamente o processo penal. Aliás, o processo inquisitório foi construído a partir de um conjunto de instrumentos e conceitos, especialmente de verdade absoluta, onde a prisão era regra porque o inquisidor tinha à sua disposição o acusado para torturá-lo para buscar a verdade real, e que se bem realizada a confissão, o inquisidor conseguia a confissão que como rainha das provas (sistema de provas tarifadas) era suficiente para a punição. Neste sentido, inútil qualquer defesa ${ }^{18}$.

Deve-se pontuar que a passagem do sistema inquisitivo para o acusatório é antes de tudo a transição política do modelo autoritário para o democrático, de modo que democracia e sistema acusatório compartilham da mesma base epistemológica.

Porém, é preciso resgatar elementos originários dessa concepção.

As Ordenações do Reino de Portugal a adotaram e a restauração monárquica empreendida por Afonso III e D. Dinis, deste modelo, valeu-se largamente, uma vez que a centralização monárquica foi conquistada com a reestruturação da ordem judiciária e processual e o consequente enfraquecimento as justiças senhoriais dos feudos.

No reinado de D. João foi realizado trabalho de recompilação das leis do Reino, resultando nas Ordenações Afonsinas, em que no Livro V restava evidente a notável influência canônica e o uso do

\footnotetext{
${ }^{16}$ WOLKMER, Antonio Carlos. História do Direito no Brasil. Rio de Janeiro: Forense, 1998.

${ }^{17}$ FOUCAULT, Michel. Em defesa da sociedade. Curso no Collège de France (1975-1976). São Paulo: Martins Fontes, 1999.
} 
procedimento inquisitivo.

Com D . Manuel, em 1521, nova codificação é empreendida - as Ordenações Manuelinas - e depois as Filipinas, cuja sob a égide eram constantes as devassas gerais (inquirições para informação de delitos incertos) ${ }^{19}$.

Quando D. João VI chegara ao Brasil em 1808, a distribuição da Justiça era confundida entre funções administrativas e judiciais e até a independência tudo era provisório, pois se mantinha o sentimento da volta a Portugal ${ }^{20}$.

No entanto, paulatinamente o processo de separação da justiça foi se dando, a exemplo de decretos e alvarás, até que em 18 de junho de 1822, D. Pedro cria juízes de fato para julgamento de crimes de imprensa contra o império e determina a observância no disciplinamento da constituição da monarquia portuguesa de 1821, destacando-se algumas garantias como a proibição de ser preso sem culpa formada, impor a lei penal apenas por necessidade, proporcionalidade e pessoalidade da pena, além de abolir pena infamantes e tortura.

As palavras do Imperador em 23 de maio de 1821, quando assume a regência do país é significativa:

Vendo que nem a constituição da Monarquia Portuguesa, nem as disposições expressas na Ordenação do Reino, nem mesmo a Lei da Reformação da justiça de 1582, com todos os outros Alvarás, Cartas Régias e Decretos de meus Augustos avós, têm podido afirmar de um modo inalterável, como é de Direito Natural, a segurança das pessoas; E constatando-me que alguns Governadores, Juízes Criminais e Magistrados, violando o sagrado depósito da jurisdição que se thes confiou, mandam prender por mero arbítrio, e antes de culpa formada, pretextando denúncias em segredo, suspeitas veementes e outros motivos horrorosos à humanidade, para impunemente conservar em masmorras, vergados com o peso dos ferros, homens que se congregam por os bens que lhes oferecera a instituição das sociedades civis, $\mathrm{O}$ primeiro dos quais, é sem dúvida, a segurança individual; E sendo o mei dever e desempenho de minha palavra o promover o mais austero respeito à lei e antecipar quanto se possa os beneficios de uma constituição liberal, ei por bem excitar pela maneira mais eficaz e rigorosa a observância da sobremencionada legislação, ampliando-a e ordenando como por este Decreto ordeno:

1- que desde a sua data em diante nenhuma pessoa livre no Brasil possa jamais ser presa sem ordem por escrito do juiz ou magistrado criminal do território, exceto somente o caso de flagrante delito, em que qualquer do povo deve prender o delinquente... ${ }^{21}$.

É verdade que, para a promulgação da Constituição do Império, o clima político ainda era de instabilidade, sem se saber qual era a real intenção do Imperador: se de desvinculação da Coroa portuguesa ou meramente adaptação num processo de recolonização, uma vez que em Portugal, vigiam as Cortes Gerais Extraordinárias e Constituintes da Nação Portuguesa, cuja uma das pretensões era fazer o imperador voltar.

Neste sentido, D. Pedro, em resposta às pressões lusitanas, assevera a criação destas cortes gerais no Brasil, cujo objetivo era "verificar a viabilidade da aplicação ao Brasil da Constituição em elaboração pelas Cortes

\footnotetext{
${ }^{18}$ COUTINHO, Jacinto Nelson de Miranda. Introdução aos princípios do Direito Processual Penal brasileiro. In: Separata ITEC, ano $1, \mathrm{n}^{\circ} 4-\mathrm{jan} / \mathrm{fev} / \mathrm{mar} 2000, \mathrm{p} .3$.

${ }^{19}$ MARQUES, José Frederico. Elementos de Direito Processual Penal. Vol. I. São Paulo: Forense, 1961.

${ }^{20}$ NEQUETE, Lenine. O poder judiciário a partir da independência. Brasília: STF, 2000.
} 
(portuguesas), estabelecer as emendas, assim como deliberar sobre as justas condições em que o Brasil deveria permanecer unido a Portugal"22.

Tratava-se de um clima inseguro sobre os destinos do país, o qual foi dissipado com a declaração da independência de 1822, mas novamente cogitado, quando o imperador não jurou a Carta Constitucional, condicionando-a: "se fosse digna do Brasil e de mim"23, tomando para si a decisão final sobre a provação ou não do texto constitucional, terminando por encerrar as atividades da Câmara, sob a justificativa de que a constituição que outorgaria seria "duplicadamente mais liberal, do que a que a extinta Assembléia acabou de fazer".

Os ideais liberais tiveram a maior divulgação por "Hipólito da Costa (1774-1823), brasileiro do sul do país que, por cerca de 15 anos editou, regularmente, o Correio Braziliense"24, o qual trazia às elites locais todas as informações, e que terminou resultando na constituição de um período florescente de garantias individuais. Aliás, "liberalismo e regime monárquico são praticamente sinônimos, coisa que só pode parecer um paradoxo aos menos avisados, muitos dos quais ainda erroneamente identificam monarquismo como absolutismo"25.

Além do liberalismo e da monarquia, a caraterística intrigante da Constituição do Império foi a criação de um poder moderador, sob explícita influência de Benjamim Constant; em que o Imperador funcionaria como equilibrador de todos os outros poderes, contrariando a tradição inglesa (como originariamente fora pensado por Constant) e que o rei reina, mas não governa.

Um dos mais defensores do Poder Moderador, um importante pensador da época, o Visconde do Uruguai, afirmava

A constituição, com muita sabedoria, não quis que algum dos Poderes governasse exclusivamente. Deu a cada um o seu justo quinhão de influência nos negócios do País. O que deu à Assembléia Geral é importantíssimo, é sem dúvida o maior. Mas ela não poderia absorver em si os quinhões dos outros poderes, sem destruir pela base a Constituição. E a Nação reservou-se, [...] o direito de rever e decidir definitivamente, nos comícios eleitorais, as soluções, por assim dizer provisórias, mas importantes dadas pelo seu primeiro representante e delegado privativo, o Poder Moderador ${ }^{26}$.

A verdade é que as tensões políticas definiram o clima do primeiro período imperial, pois a estabilidade

\footnotetext{
${ }^{21}$ Apud.JÚNIOR, João Mendes. O Processo criminal brasileiro. vol. I, 1901, p. 149.

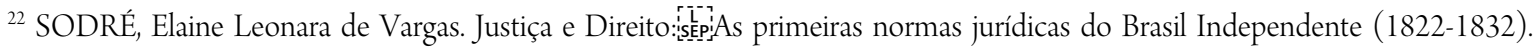
Revista do corpo de discente do programa de Pós-Graduação de História da UFRGS, Rio Grande do Sul, n. 4. V. 2, p. 179-188, nov., 2009.

${ }^{23}$ CUNHA, Pedro Octávio Carneiro da. O movimento da Independência. História Geral da Civilização Brasileira. Tomo II, p. 180

${ }^{24}$ SOUZA, Alexandro. Panorama da história do liberalismo no Brasil. Revista de Estudo interdisciplinar ibéricos e íberosamericanos, Juiz de Fora, ano I, n. 4, p. 57-67, jun-ago, 2007, p. 60.

${ }^{25}$ PENNA, Apud. SOUZA, Alexandro. Panorama da história do liberalismo no Brasil. Revista de Estudo interdisciplinar ibéricos e íberos-americanos, Juiz de Fora, ano I, n. 4, p. 57- 67, jun-ago, 2007.
} 
do Império e somente era objeto de preocupação, das elites e dos pensadores. Se antes da dissolução da Assembleia se discutia outras matérias, como a motivação para a cidadania plena (inclusive para escravos) ou restrita, cujas reservas eram dadas em razão do medo de insurreições, como acontecera nas Antilhas ${ }^{27}$, essa dúvida fora dissipada com a outorga da Carta, restando, somente a questão da centralização política.

Outrossim, não existia uma estrutura judiciária consagrada e fortalecida, cabendo aos códigos vindouros a sua organização, a qual, pós-constituição passou a ser racionalizada, com o confinamento das atribuições eclesiásticas às questões da igreja, e a separação de poderes, que até então tinha no Judiciário funções próprias e de administração. Aliás, o Imperador na reabertura dos trabalhos da Assembleia em 1825 declarara: "Recomendovos de novo a administração da Justiça. O sistema constitucional exige imperiosamente a completa organização do Poder Judiciária, pois o tempo todo se gastava em pequenas leis, que deixavam o problema sem solução"28.

O que existia até então era "o arcabouço administrativo existente naquele momento, havia sido organizado pela corte joanina. O aparato estatal passou a se instrumentar por diversos meios. Numa acepção simplificadora: o objetivo era monopolizar o poder" ${ }^{29}$. Uma discussão significativa já que havia passado oito anos após a Constituição para a entrada em vigor da legislação que viria organizar o Poder Judiciário, e tendo sido promulgada depois de D. Pedro I deixar o Brasil, o elemento de resistência à descentralização não existia mais.

O destaque à organização do Poder Judiciário, além de fortalecer a autoridade do poder central, colocando o Estado como administrador da justiça, era também um benefício para as elites, pois seriam contempladas na elaboração e na execução de leis, eis ai, talvez, a justificação por uma atuação tão ativa das elites políticas na construção de um novo Estado, pois se o processo esteve longe de ocorrer sem tensões e conflitos, também se deu no interesse de muitos ${ }^{30}$.

O fato é que a Constituição do Império de 1824 apresentou-se dotada de ideias liberais, afastando as práticas das Ordenações, fazendo com que o posterior Código de Processo Criminal de 1832 "o diploma culminante e mais expressiva síntese que é dos anseios humanitários e liberais que palpitavam no seio do povo e da nação" 31 .

\footnotetext{
${ }^{26}$ Apud. SOUZA, Alexandro. Panorama da história do liberalismo no Brasil. Revista de Estudo interdisciplinar ibéricos e íberosamericanos, Juiz de Fora, ano I, n. 4, p. 57- 67, jun-ago, 2007, p. 62.

${ }^{27}$ WEHLING, Arno. O escravo ante a lei civil e penal no Império. In: WOLKMER, Antônio Carlos (org.). Fundamentos de História do Direito. 2 ed. Belo Horizonte: Del Rey, 2003.

${ }^{28}$ NEQUETE, Lenine. O poder judiciário a partir da independência. Brasília: STF, 2000, p. 44.

${ }^{29}$ SODRÉ, Elaine Leonara de Vargas. Justiça e Direito:șẹp:As primeiras normas jurídicas do Brasil Independente (1822-1832). Revista do corpo de discente do programa de Pós-Graduação de História da UFRGS, Rio Grande do Sul, n. 4. V. 2, p. 179-188, nov., 2009.

${ }^{30}$ CUNHA, Pedro Octávio Carneiro da. O movimento da Independência. História Geral da Civilização Brasileira. Tomo II, 201 1, p. 17.

${ }^{31}$ MARQUES, José Frederico. Elementos de Direito Processual Penal. Vol. I. São Paulo: Forense, 1961, p. 96
} 
Até a promulgação do Código de Processo, as experiências do Poder Moderador foram tensionadas por discussões de centralização e descentralização, cujo emblema é encontrado na Confederação do Equador, em que Frei Caneca, recusou-se à jurar à Constituição, considerando-a, especialmente no que tange ao Poder Moderador, "a chave mestra da opressão da nação brasileira"32.

As vicissitudes do primeiro reinado, eivado de controle comercial por parte de Portugal, projetando déficit da economia brasileira, as consequências da Noite das Garrafadas, fizeram com que D. Pedro I renunciasse, passando o trono a seu herdeiro, e deligando completamente os laços com Portugal.

Com isso, era necessário uma reorientação das relações entre as elites locais e o Estado, aquelas compostas, significativamente por bacharéis sem representação classista, sem compromisso, portanto, com as questões de centralização e descentralização. $\mathrm{Na}$ verdade, com a abdicação, decisões entre República ou monarquia, unitarismo ou federalismo, eram decisões prementes.

O fato é que o Código foi elaborado em meio a ferrenhas aclamações dos liberais de modernização da organização da justiça, fundamentada, especialmente na descentralização, o que foi sobejamente atendido por meio da criação de um municipalismo judicializado, consagrado pelos juízes de paz - eleito - e júri popular, cuja intervenção do poder central não atingia, limitando-se à magistratura profissional, lotada nas comarcas.

O autor do Projeto de Lei foi o senador Manuel Alves Branco, apresentado em 1831, sobrepondo-se a dois outros mais antigos, discutidos desde 1828, cuja demora, segundo Thomas Flory pode ter decorrido em razão da má técnica daqueles, tendo em vista que em maioria dos deputados eram magistrados profissionais e "encontraron fallas organizativas y percibieron la importancia política de la medida"33.

Nesse sentido, como dito, foi o bacharelismo no Brasil um movimento de notável importância, já que é esta a elite que vai determinar os caminhos do Judiciário no Brasil, cujas decisões e escolhas forjadas por esse grupo eram pulverizadas pelo interior do império por meio de uma cadeia de funcionários do Estado composta por juízes, delegados e presidentes de provincial" 34 .

Bacharel representava oportunidade preferenciais para o ingressos nos cargos públicos da burocracia estatal, assegurando prestígio e poder.

Representavam as Faculdades de Direito de Olinda e do Largo de São Francisco em São Paulo, os polos

\footnotetext{
32 Apud. OlIVEIRA, Cecília Helena de Salles. O PODER MODERADOR NO SEGUNDO REINADO - MEDIAÇÕES ENTRE FONTES E HISTORIOGRAFIA, Mesa redonda da ANPUH realizada em setembro de 2002, no campus da UNESP/ Franca.

${ }^{33}$ Apud. SODRÉ, Elaine Leonara de Vargas. Justiça e Direito:s[íp: As primeiras normas jurídicas do Brasil Independente (18221832). Revista do corpo de discente do programa de Pós-Graduação de História da UFRGS, Rio Grande do Sul, n. 4. V. 2, p. 179 188, nov., 2009, p. 182.

${ }^{34}$ CUNHA, Pedro Octávio Carneiro da. O movimento da Independência. História Geral da Civilização Brasileira. Tomo II., 2011, p. 18.
} 
de conhecimento que definiriam os caminhos jurídicos do Império, cujas ideologias faziam-nas de maneira bem diferentes, no sentido de que em Olinda (transferida para Recife) - os ideais liberais eram consagrados, cuja representação tem a "particularidade, sobretudo no tocante à sua capacidade de elaborar projetos formulados para todo o Brasil, nos quais 'a questão nacional', aparentemente, sobrepõe-se aos particularismos provinciado" 35 .

Por outro lado, em São Paulo, não obstante a adesão liberal, o praxismo imperou, representado por um dos seus maiores expoentes, Pimenta Bueno; além de politicamente estar atrelada a "interesses dos setores agroexportadores, num primeiro momento, e aos setores industriais, incorporados num segundo momento".

É bem verdade que há vozes dissonantes do papel do bacharelismo na construção do Estado brasileiro, como a opinião de Nelson Saldanha, segundo o qual "falar em bacharelismo é pouco menos que alimentar um mito, a não ser que se frise que se trata de referir um bias profissional, o do que lida com leis e ditos forenses ou burocráticos; ou então uma forma mentis tendente a ver o jurídico como essência do social"36.

O fato é que o bacharelismo, independentemente de ser considerado uma instituição, consagrou-se como um fenômeno político social e ajudou na formação do ethos da estruturação do Estado e assim os caminhos do funcionalismo público, assegurados pelo bacharelismo, fez com que o liberalismo fosse, durante longo tempo, conhecimento detido apenas por uma elite intelectual e o Bacharel que fez da política vocação, lutou pelo êxito das causas e que se apaixonou e transformou a política em atividade ética, em verdadeira cruzada civilizatória. No entanto, contrariamente ao que ocorreu no mundo europeu ocidental, na sociedade brasileira a profissionalização da política não foi acompanhada da democratização da sociedade ${ }^{37}$.

A grande influência do bacharelismo se dá exatamente na luta contra o monopólio metropolitano, engajando-se na luta contra o agrarismo e o escravagismo, menos nestes, dada a classe intelectual era aristocrata, e mais aquela, a ponto de delinear a organização judiciaria do país.

Nesse sentido, a interpretação dada por alguns historiadores, como Carvalho ${ }^{38}$, é a de que a construção do país foi dada por um grupo de políticos bacharéis, sendo secundária, portanto a participação das elites locais, os proprietários de terras e grandes comerciantes, imiscuindo-se, apenas em relação a assuntos de agroexportação.

Por outro lado, outros historiadore ${ }^{39}$ entendem que a elite proprietária interferiu na condução política e

\footnotetext{
${ }^{35}$ NEDER, Gizlene. Discurso Jurídico e Ordem Burguesa no Brasil. Porto Alegre: Sérgio Antonio Fabris, 1995, p. 105

${ }^{36}$ Apud. KOZIMA, José Wanderley. Instituições, retórica e o bacharelismo no Brasil. In: Wolkmer, Antônio Carlos (org.). Fundamentos de História do Direito. Belo Horizonte: Del Rey, 2003, p. 350.

${ }^{37}$ MEIRELLES, Delton Ricardo Soares. Magistrados e processo: impressões da literatura jurídica nacional (1832-1876). Anais. XVII Congresso Nacional do CONPEDI, Brasília, 2008, p. 5796

${ }^{38}$ CARVALHO, José Murilo. Os bestializados. O Rio de Janeiro e a República que não foi. 3 ed. São Paulo: Companhia das Letras, 2004,

${ }^{39}$ GRAHAM, Richard. Apud. CUNHA, Rogério Pereira da. Juízes, policiais e administradores: elites locais, juízo municipal e centralização provincial na formação do Estado no Brasil - São Francisco do Sul, província de Santa Catarina (1832-1850). Dissertação. UFPA, Curitiba, 2011, p. 20.
} 
na forma de administração das instituições. Para ele, as elites locais gradativamente se apropriaram das instituições estatais inseridas nos municípios, como o juízo de paz e municipal. E nesse sentido, a autonomia provincial sobrepujou a centralização política e as elites provinciais conseguiram ditar as suas escolhas para o Estado.

Foi na verdade, esse útimo o projeto político que venceu, forçando a promulgação do Código de Processo Criminal.

\section{O CÓDIGO DE PROCESSO PENAL E A ESTRUTURAÇÃO DO PODER JUDICIÁRIO DO IMPÉRIO}

Uma das grandes contribuições da novel legislação foi organizar a Administração da Justiça do Império. Assim, o Código dividiu o Império em Distritos de Paz, Termos e Comarcas, nos quais, haveria uma estrutura judiciaria específica.

Nas disposições preliminares estrutura como tendo em cada distrito, juízes de paz, escrivães de paz, oficiais de justiça e inspetores, sendo aqueles eleitos pela comunidade local e estes nomeados pelas Câmaras Municipais, mediante indicação do juiz de paz com exceção do inspetor que era nomeado pelo juiz de paz.

A jurisdição é a mais ampla possível, administrativa, desde a expedição de passaportes para quem desejasse viver no distrito, à policial - com a assinatura do termo de segurança e judicial com o juízo de formação da culpa (condução do processo penal), que em caso de procedimento ordinário seria encaminhado ao júri de acusação, nos distritos, que, caso formasse um juízo positivo, seguiria para o júri de sentença.

Trata-se de esquema verdadeiramente inquisitivo. Um exemplo disso está no art. 13, par. 3, em que o juiz de paz está autorizado a obrigar que os suspeitos da pretensão de cometer crime assinem termo de segurança, quando ele mesmo, iria mais a frente proceder ao auto de corpo de delito, prender culpas, conceder fiança e formar o juízo de culpa - garantia conquistada ante o inquisitivo Livro V das Ordenações Filipinas, anteriormente vigente.

Mas não somente, sendo os inspetores de nomeação dos juízes de paz, nada mais do que confundir num só espaço funções executivas e judiciarias. E mais, por esses inspetores serem dispensados do serviço militar de 1 linha e das Guardas Nacionais (art. 17), serviços extremamente desgastantes, especialmente num cenário de guerras, estabelecia-se um elo de proteção, clientelismo e nas relações entre esses dois membros do serviço público.

A verdade das funções policiais do juiz de paz é tão evidente que na Reforma de 1841, que se deu um levante de centralização, o Senador Alves Branco (que também fora quem apresentou o CPC de 1832), afirmara 
devendo ser a polícia presente em todos os lugares onde se podem cometer crimes, era indispensável que esse magistrado tivesse em todos eles agentes que dessem execução às suas ordens e às leis policiais; e então [...] as autoridades existentes nos termos e distritos devem ser revestidos de funções policiais, não só porque hoje já se acham revestidos de grande parte dessas funções, mas porque cumpria dar unidade às ações ${ }^{40}$.

Enfim, todo esse sistema de organização da administração da justiça estava imbuído em uma crítica aos juízes de carreira que, na opinião de muitos liberais, eram influenciados pelos interesses do governo. Sendo assim, os cargos ocupados por não profissionais serviam para reduzir os danos da influência do Estado, ou seja, "a imparcialidade da justiça não vinha do governo e dos funcionários de carreira e sim de uma justiça eleita no município, controlada pelos cidadãos" ${ }^{11}$.

Essa tensão aponta para os embates em torno da formação do Estado no Brasil na medida em que se percebem as negociações em torno da participação dos diversos setores no Estado e, sobretudo, as maneiras como os grupos discutiam e negociavam os seus papéis.

Com essa estrutura, deu-se maior autonomia aos proprietários rurais das províncias que poderiam escolher seus representantes políticos - juízes de paz - autoridade judicial do município eleito pela comunidade. Com isso, deu-se a fomentar a disseminação do poder pela sociedade a partir das estruturas municipais.

Assim, reforça-se as posições do judiciário local, permitindo às elites locais participação na construção do Estado por meio do processo de escolha dos ocupantes e da ocupação efetiva dos cargos do judiciário local.

A centralização, portanto, para Graham ${ }^{42}$, foi diretamente afetada pelos interesses da elite proprietária ciosa pela manutenção da ordem e da escravidão na medida em que as instituições fossem orientadas para esse fim. O Estado passa a ser um instrumento que reproduz o modelo de autoridade das localidades e um empecilho para o afloramento dos faccionalismos locais, que quase levaram o Brasil à desagregação e ao reformismo social. A manutenção da ordem e do unitarismo levou esses proprietários a acreditarem na centralização e a abandonarem as ambições de autonomia local.

Enfim, o Estado, sofrendo a influência desse setor, funcionava para reafirmar as hierarquias sociais, manter a ordem e favorecer uma minoria.

$\mathrm{Na}$ interpretação de Raymundo Faoro ${ }^{43}$, as relações estabelecidas entre indivíduo e Estado é uma manifestação de uma cultura patrimonial herdade desde a Colônia, em que a forma de dominação é realizada pela

\footnotetext{
${ }^{40}$ NEQUETE, Lenine. O poder judiciário a partir da independência. Brasília: STF, 2000, p. 66.

${ }^{41}$ COSER. Apud. CUNHA, Pedro Octávio Carneiro da. O movimento da Independência. História Geral da Civilização Brasileira. Tomo II, 2011 , p. 28.

${ }^{42}$ GRAHAM, Richard. Apud. CUNHA, Rogério Pereira da. Juízes, policiais e administradores: elites locais, juízo municipal e centralização provincial na formação do Estado no Brasil - São Francisco do Sul, província de Santa Catarina (1832-1850). Dissertação. UFPA, Curitiba, 2011, p. 20.

${ }^{43}$ FAORO, Raymundo. Os Donos do Poder: formação do patronato político brasileiro. 2 vol. 4 ed. Porto Alegre: Globo, 1977.
} 
tradição e que se exerce em um quadro administrativo e militar em virtude de um pleno direito pessoal, formandose assim, o clientelismo e o favoritismo, resultando na superposição do Estado a uma sociedade civil desarticulada e dependente. Era este o cenário da reprodução das relações familiares numa sociedade extremamente agrária.

Entretanto, o argumento do clientelismo e da proteção em troca de ordem e obediência por meio da coisa pública, também se baseia pelo fato de o governo regencial não se apresentava nas localidades e a presença de bacharéis não se apresentava nas localidades efetivamente, pois até então a matrícula nos cursos de Coimbra não era uma constante. Não por que a elite era pobre, mas sim porque optava-se por investir os lucros do comércio de farinha, madeira, arroz e cal em novos fatores de produção, sobretudo escravos ${ }^{44}$.

Por outro lado, aqueles bacharéis que existiam no país, em razão do precário ensino das faculdades, não se formava um corpo intelectual coeso e preparado, de modo que ser bacharel ou não em muito não importava nos caminhos designados pela política, afinal, teoria e prática eram completamente distorcidas, pois sendo patrimonial, as ordens eram de cima para baixo - e nesse contexto patriarcalista o discurso liberal era retórico ${ }^{45}$.

Contudo, os liberais reformistas não tinham nenhum controle sobre esses juízes, de modo que somente com muita cautela alguns deles podem ser denominados como agentes policiais do governo. O que predominava era o uso das atribuições para fazer valer os interesses pessoais.

Nos termos, assegura-se a seguinte estrutura: Conselho de Jurados, Juiz Municipal, Promotor Público, Escrivão das execuções e oficiais de justiça. O juiz municipal, era um bacharel formado em Direito, mas não necessariamente, e por estar vinculado ao Termo, e ser de nomeação mista (indicação da Câmara municipal e nomeação do governo da província), representava a centralização política e com isso, as elites e as autoridades provinciais interagiam-se, pois afinal, "Não bastava somente ser poderoso na vila, pois era necessário ter capacidade de transpor a âmbito estritamente local para se lançar a condição de elite provincial" ${ }^{46}$.

As funções desses juízes eram ambígua, pois cabia a ele executar as ordens dos juízes do Termo e exercitar cumulativamente função policial. Outra novidade significativa era o júri. Os jurados, eram escolhidos por listas em cada distrito, formada por uma junta composta pelo juiz de paz, parocho e o presidente ou algum vereador.

Já nas Comarcas, havia os juízes de direitos, estes sim, nomeados pelo Imperador entre os bacharéis formados em Direito, que tinha a competência de presidir os júris e proceder as tratativas relativas ao funcionamento deste e inspecionar os juízes de paz.

\footnotetext{
${ }^{44}$ CUNHA, Pedro Octávio Carneiro da. O movimento da Independência. História Geral da Civilização Brasileira. Tomo II, 2011. ${ }^{45}$ KOZIMA, José Wanderley. Instituições, retórica e o bacharelismo no Brasil. In: Wolkmer, Antônio Carlos (org.). Fundamentos de História do Direito. Belo Horizonte: Del Rey, 2003.

${ }^{46}$ CUNHA, Pedro Octávio Carneiro da. O movimento da Independência. História Geral da Civilização Brasileira. Tomo II, 2011, p. 12.
} 


\section{Principais desafios e contribuições liberais do Código de Processo Criminal do Império}

O que havia de frágil eram normas de organização judiciaria e a regulamentação do júri e fez com que entre 1830 e 1840 (período de revoluções) existisse uma reação anti-liberal e uma contra reação da monarquia conservadora, posto que o Imperador passou a entender que o Código não era mais capaz de conter as rebeliões e manter a ordem e a tranquilidade.

O resultado da Reforma de 1841 foi um instrumento de driblar a desordem e restabelecer a autoridade imperial. Para isso, concedeu poderes judiciários às autoridades policiais, criando um aparelho policial centralizado e armado - denominado de judiciarismo policial.

A reforma de 1841 deixou evidente as divisões do Código do procedimento e da organização judiciaria, pois enquanto aquele permanecia de cunho liberal, esta organização ao conceder poderes judiciais (formação da culpa, por exemplo) às polícias violou qualquer elemento liberal. Esta situação levou Duarte de Azevedo a afirmar que "enquanto na França eram dados aos juízes função policial, no Brasil, se dava função judicial à polícia" ${ }^{2}$.

Mirian Dolhnikoff entende que a autonomia adquirida pela elite provincial a partir da lei de 1834 permitia-lhes atender seus principais interesses. Essa autonomia é que garantia a adesão das elites provinciais ao Estado que se construía. Uma das demandas da elite provincial era limitar a ação dos juízes locais que usavam as atribuições recebidas no Código do Processo Criminal de 1832 para ampliarem seu poder privado. Essa era a causa dos conflitos entre as facções locais que faziam uso dos cargos do judiciário para alimentar as disputas municipais. Essa autora não reconhece nas reformas do período de 1837-1841 uma fissura entre federalistas e centralizadores, pois, na sua leitura, o que estava no centro das discussões era estabelecer nitidamente quais eram as prerrogativas do governo central e do poder provincial. Nesse sentido, foi operada uma divisão clara, garantindo a centralização judiciária e a autonomia administrativa das províncias. Era o equilíbrio entre centralização política e descentralização administrativa ${ }^{48}$.

Estabelecia-se, um consenso entre as elites, desse modo, que a função judiciária era objeto de manobras particulares e considerando que os juízes de paz eram leigos, despreparados, as críticas passaram a ser contumazes.

Era a investida da defesa social, a qual em 1854, Nabuco de Araújo apresenta à Câmara legislação de combate ao policialismo e fortalecimento da justiça togada, inclusive em detrimento do júri. A impressão é a de que a autonomia concedida aos distritos ao elegerem seus juízes de paz foi uma forma de costurar um jogo

\footnotetext{
${ }^{47}$ Apud. MARQUES, José Frederico. Elementos de Direito Processual Penal. Vol. I. São Paulo: Forense, 1961, p. 99.

${ }^{48}$ CUNHA, Pedro Octávio Carneiro da. O movimento da Independência. História Geral da Civilização Brasileira. Tomo II, 2011 , p. 44.
} 
político entre a tensão de forma unitária e federativa da monarquia, então essa autonomia concedida foi uma forma de ajuste de intenções, garantindo o atendimento dos desejos das elites agrícolas - conservadoras - e o próprio poder do monarca.

No entanto, essa autonomia fez fugir do controle do imperador as dissensões existentes em cada espaço de Comarca, abrindo espaço para o apoio, inclusive, das elites, das revoluções que passaram a acontecer, ensejando, assim o enrijecimento policialesco da jurisdição, para descontentamento dos liberais.

Dessa forma, é fácil identificar como o processo criminal é manejado ao sabor das demandas sociais autoritárias ou liberais, variando conforme o estado social apresentado.

De outro modo, a legislação previu algumas instituições de cunho liberal, como a prescrição, as audiências, as suspeitas e recusações.

O início da persecução penal se dava mediante queixa ou denúncia, com o detalhe de que esta poderia ser promovida pelo promotor público ou qualquer do povo, conforme art. 74. A diferença se um ou outro instrumento, iria depender dos delitos (art.74).

As provas são oferecidas pelas partes ou promovida ex officio (art. 84) e tinham caráter tarifário, apesar de não restar explícito no texto, mas decorrer do fato de o juiz valorar conforme entender (art. 89) e que a confissão seria suficiente para a prova.

O processo em si compreendia o sumário, no qual estava englobado a expedição de passaporte, o termo de bem viver e de segurança, a prisão sem culpa (decorrente de flagrante - art. 131....). é importante assinalar que o auto de prisão em flagrante é formado pelo juiz de paz (art. 131) que é o mesmo que recebe a denúncia ou a queixa (art. 77, par. 1), deixando um claro exemplo de elementos inquisitivos. Ainda no sumário dá-se a formação da culpa, cuja denúncia pode ser realizada sem ou com auto de corpo de delito (o que seria o inquérito); e no caso de denúncia, mesmo que não haja denunciante, o juiz pode inquirir testemunhas e autuar de ofício do auto de corpo de delito (art. 141); um traço marcadamente inquisitivo em que o julgador se presta a busca de provas.

Há um procedimento específico para apuração de crimes de responsabilidade dos empregados públicos, cujo processamento é realizado pelas Câmaras Legislativas ou ao governo ou aos presidentes das províncias ou as autoridades judiciarias, podendo ser intentada, inclusive ex officio (art. 154 e 156), cabendo, inclusive remessa de ofício em casos de não pronunciamento do juízo de culpa.

Na proclamação das sentenças do juiz de paz, o julgamento pode ser realizado com a ausência do réu, e mesmo sem queixa ou denúncia, caso em que o juiz conhecendo infração às leis policiais, ou termo de segurança e de bem viver, mandará formar o auto circunstanciado do fato (art. 206).

Ainda há a possibilidade de recurso à Junta de Paz (art. 213), admitindo, inclusive, julgamento à revelia, caso o réu não compareça, sem escusa legítima ( art. 221). 
Encerrado o procedimento sumário com a formação da culpa, passa-se ao procedimento ordinário, no qual a acusação será formada pelo conselho de jurados - júri de acusação que em sendo o juízo acerca do delito positivo, segue para o conselho de sentença.

Além de vários outros institutos o habeas corpus é um instrumento de novidade de garantia liberal que se apresenta pela primeira vez no Brasil. (art. 340 em diante), podendo ser requerido por qualquer cidadão do povo ou concedido de ofício tem hipótese ampla, ao se referir o legislador a qualquer prisão ou constrangimento ilegal (art. 353).

Em resumo, as duas grandes revoluções causadas pelo Código de Processo, em termos técnicos é a previsão do habeas corpus e a instituição do Júri, como máxima representação popular do Império.

Enfim, como se vê, a compressão histórica do processo criminal a partir da promulgação da primeira legislação no Império é de fundamental importância para a compreensão da ambiguidade de fenômenos que permeiam a prática processual atual, seja manifestada na própria legislação ou na cultura jurídica dos operadores do Direito.

É o caso por exemplo de alguns atribuírem ao processo penal brasileiro uma conotação mista inquisitivo na fase policial e acusatório na fase judicial, o que porém, como relata Jacinto Coutinho, esse sistema bifásico, herdado do código napoleônico, é monstro de duas cabeças, acabando por valer mais a prova secreta que a do contraditório, numa verdadeira fraude ${ }^{49}$.

O que se pretendeu nesse texto foi problematizar a miscelânea de modelos processuais existentes no Estado brasileiro desde o seu primeiro documento jurídico, o que pode guardar diversos obstáculos históricos, mas sobretudo culturais, à construção democrática do Estado de Direito, afinal não obstante o modelo acusatório ter sido inaugurado com a Constituição de 1988, apesar de elementos liberais já estarem presentes desde a promulgação do primeiro Código de Processo Criminal do Império, aquele documento conviveu com cenários políticos que levaram também, à presença de diversos elementos inquisitivos, de modo a não se tornar, inteiramente uma legislação liberal.

Nesse caso, quer-se dizer que o Estado nunca consolidou o monopólio sobre a violência física e nunca conseguiu estatuir leis confiáveis, que mediassem as relações entre os indivíduos. O resultado foi que, em lugar de uma reversão das relações agressivas, o que existiu, ao longo de toda sua história, foi a persistência de valores que cultuam a força como alternativa amplamente utilizada entre a população para solucionar conflitos ${ }^{50}$

\footnotetext{
${ }^{49}$ COUTINHO, Jacinto Nelson de Miranda. Introdução aos princípios do Direito Processual Penal brasileiro. In: Separata ITEC, ano $1, \mathrm{n}^{\circ} 4-\mathrm{jan} / \mathrm{fev} / \mathrm{mar} 2000$.

${ }^{50}$ LIMA, Antônio José Tavares de. Violência e Cultura brasileira. Saber Jurídico , v. IX, p. 05, 2013, p. 5.
} 
Assim, a abordagem de Garland ${ }^{51}$ sobre os micro interesses sociais faz todo sentido: é preciso conhecer as raízes estruturantes da cultura brasileira para se pensar analiticamente o controle punitivo.

Em resumo: a violência foi manejada para garantir a ordem, o que leva à aceitação social e legitimidade que perdurou até a ditadura, foi incorporada na cultura política como elemento da vida brasileira, o que leva à conclusão de que, qualquer discurso que se pretenda superar a prática social violenta, deve dialogar com esse traço da realidade, e nesse caso o saber criminológico não pode decurar, afinal "Ainda que os regimes autoritários estejam em baixa, a reflexão precedente nos propicia o entendimento que o pensamento autoritário conservador tem uma lógica de longa duração na América Latina" ${ }^{52}$. Essas ideias encontram, aqui, um campo fértil.

O processo penal pode ser um ótimo instrumento de veiculação desses paradoxos.

\section{CONSIDERAÇÕES FINAIS}

Percebeu-se que a promulgação do Código de Processo Criminal de $1^{\circ}$ Instância do Império atendeu a demandas políticas e sociais específicas do momento, o que fica muito evidente na estruturação descentralizada do Poder Judiciário, dotado de pessoas sem o preparo jurídico, até porque os cursos de Direito eram apenas o qualificativo (status) para a entrada na burocracia do Estado, e não produção de conhecimento.

A composição do Poder Judiciário atendeu aos interesses provinciais, dado que os proprietários rurais poderiam escolher seus representantes políticos - juízes de paz - que funcionavam como autoridade judiciária municipal, sem qualquer interferência do Imperador.

Tratava-se, na minha opinião, de um pacto de cavalheiros, pois precisava o Império reestruturar o Poder Judiciário para conquistar a centralização monárquica, tão desejada pelo Imperador (centralização cujo ápice é o poder moderador), mas que não detinha pessoas suficientes para ocupar os cargos nas diversas províncias, nem força política e financeira de se contrapor aos proprietários rurais, que até então realizavam as suas justiças senhoriais.

Então, com o influxo das ideias liberais, deu-se a revogação do Livro V das Ordenações, a promulgação da Constituição do Império e a adequação do Código de 1832, contemplando garantias fundamentais, como a liberdade, com a previsão do habeas corpus.

Por outro lado, o exercício dessas garantias era muito escassa, sobretudo, em razão do coronelismo que ainda se exercia, afinal os juízes de paz tinham uma vinculação política com eles (eram escolhidos pelos

\footnotetext{
${ }^{51}$ GARLAND, David. A cultura do controle. Crime e ordem social na sociedade contemporânea. Rio de Janeiro: Revan, 2008.

52 WASSERMANN, Cláudia. Raízes do pensamento autoritário na América Latina. In: ABREU, Luciano Aronne de; MOTTA, Rodrigo Patto Sá (Orgs.). Autoritarismo e cultura política. Porto Alegre: FGV; Edipucrs, 2013, p. 205.
} 
proprietários rurais). No entanto, era a manifestação hipócrita do bacharelismo de que a lei era capaz de transformar a realidade, um resquício que a sociedade brasileira ainda vivencia nos dias atuais.

\title{
THE CÓDIGO DE PROCESSO CRIMINAL DE PRIMEIRA INSTÂNCIA: FROM THE CONTEXT TO THE IMPERIAL TEXT AND THE INFLUENCES IN NOWADAYS
}

\begin{abstract}
The author debates the cultural relation between Código de Processo Criminal de primeira instancia, first procedure document in Brazil, presented like liberal, and the actual procedure criminal model. Critic history of Law and bibliography review was used to contextualize the political moments when the document was created and from this the objective was display a knowledge about this origin and to identify cultural remnants to build strategies to overcome inquisitive elements represented in Brazil's procedural models, in the way to fundamental guarantees.
\end{abstract}

Keywords: procedural models; Critic history of Law; Código de Processo Criminal de primeira instancia

\section{REFERENCIAS}

ADORNO, Sérgio. Insegurança versus direitos humanos. Entre a lei e a ordem. Tempo Social; Rev. Scoiol. USP, São Paulo, 11 (2): 129-153, out. 1999.

BELLI, Benoni. Tolerância Zero e democracia no Brasil: visões da segurança pública na década de 90. São Paulo: Perspectiva, 2004.

BRASIL. Decerto de 12 de novembro de 1823, Coleção das Leis do Império Brasil, Parte II, 1823.

CARVALHO, José Murilo. Os bestializados. O Rio de Janeiro e a República que não foi. 3 ed. São Paulo: vol.11, no. 04, Rio de Janeiro, 2018.pp. 2730-2751 
Companhia das Letras, 2004.

COUTINHO, Jacinto Nelson de Miranda. Introdução aos princípios do Direito Processual Penal brasileiro. In: Separata ITEC, ano 1, no 4 - jan/fev/mar 2000.

CUNHA, Pedro Octávio Carneiro da. O movimento da Independência. História Geral da Civilização Brasileira. Tomo II, 2011.

FAORO, Raymundo. Os Donos do Poder: formação do patronato politico brasileiro. 2 vol. 4 ed. Porto Alegre: Globo, 1977.

FAUSTO, Boris. O pensamento nacionalista autoritário (1920-1940). Rio de Janeiro: Jorge Zahar, 2001

FOUCAULT, Michel. Em defesa da sociedade. Curso no Collège de France (1975-1976). São Paulo: Martins Fontes, 1999.

GARLAND, David. A cultura do controle. Crime e ordem social na sociedade contemporânea. Rio de Janeiro: Revan, 2008.

GRAHAM, Richard. Apud. CUNHA, Rogério Pereira da. Juízes, policiais e administradores: elites locais, juízo municipal e centralização provincial na formação do Estado no Brasil - São Francisco do Sul, província de Santa Catarina (1832-1850). Dissertação. UFPA, Curitiba, 2011, p. 20.

JÚNIOR, João Mendes. O Processo criminal brasileiro.vol. I, 1901

KOZIMA, José Wanderley. Instituições, retórica e o bacharelismo no Brasil. In: Wolkmer, Antônio Carlos (org.). Fundamentos de História do Direito. Belo Horizonte: Del Rey, 2003.

LIMA, Antônio José Tavares de. Violência e Cultura brasileira. Saber Jurídico ,v. IX, p. 05, 2013.

LOPES JR., Aury. Direito Processual Penal e Sua Conformidade Constitucional. 11 ed. São Paulo: Saraiva, 2014. 
MARQUES, José Frederico. Elementos de Direito Processual Penal. Vol. I. São Paulo: Forense, 1961.

MEIRELLES, Delton Ricardo Soares. Magistrados e processo: impressões da literatura jurídica nacional (18321876). Anais. XVII Congresso Nacional do CONPEDI, Brasília, 2008.

NEDER, Gizlene. Discurso Jurídico e Ordem Burguesa no Brasil. Porto Alegre: Sérgio Antonio Fabris, 1995.

NEQUETE, Lenine. O poder judiciário a partir da independência. Brasília: STF, 2000.

OLIVEIRA, Cecília Helena de Salles. O PODER MODERADOR NO SEGUNDO REINADO MEDIAÇÕES ENTRE FONTES E HISTORIOGRAFIA, Mesa redonda da ANPUH realizada em setembro de 2002, no campus da UNESP / Franca.

OLIVEIRA, Luciano. Relendo “Vigiar e Punir”, Dilemas: Revista de Estudos de Conflito e Controle Social - Vol. 4 - nº 2, - pp. 309-338, abr/mai/jun, 2011.

A pesquisa sócio-jurídica na pós-graduação em Direito. Sua Excelência o Comissário e outros ensaios de Sociologia jurídica. Rio de Janeiro: Letra Legal, 2004.

Do nunca mais ao eterno retorno. Uma reflexão sobre a tortura. São Paulo: brasiliense, 2009.

PRADO, Geraldo. A transição democrática no Brasil e o Sistema de Justiça Criminal. Palestra proferida no Ciclo de Conferências organizado pela Faculdade de Direito, pelo Programa de Pós Doutoramento em Democracia e Direitos Humanos e pelo Centro de Estudos Interdisciplinares do Século 20 da Universidade de Coimbra em 06 de novembro de 2012, no âmbito do módulo de Direito Penal coordenado pela prof. Cláudia Santos.

SODRÉ, Elaine Leonara de Vargas. Justiça e Direito (1822-1832). Revista do corpo de discente do programa de Pós-Graduação de História da UFRGS, Rio Grande do Sul, n. 4. V.2, p. 179-188, nov., 2009.

SOUZA, Alexandro. Panorama da história do liberalism no Brasil. Revista de Estudo interdisciplinar ibéricos e íberos-americanos, Juiz de Fora, ano I, n. 4, p. 57- 67, jun-ago, 2007.

SOUZA, Jessé. A tolice da inteligência brasileira: ou como o país se deixa manipular pela elite. São Paulo: LeYa, vol.11, no. 04, Rio de Janeiro, 2018. pp. 2730-2751 2750 
2015.

SCHWARCZ, Lilia Moritz; BOTELHO, André. Um enigma chamado Brasil: 29 intérpretes e um país. São Paulo: Companhia das Letras, 2009 .

TAVARES, Juarez. Teoria do Injusto Penal. 3 ed. Belo horizonte: Del Rey, 2003.

WASSERMANN, Cláudia. Raízes do pensamento autoritário na América Latina. In: ABREU, Luciano Aronne de; MOTTA, Rodrigo Patto Sá (Orgs.). Autoritarismo e cultura política. Porto Alegre: FGV; Edipucrs, 2013.

WEHLING, Arno. O escravo ante a lei civil e penal no Império. In: WOLKMER, Antônio Carlos (org.). Fundamentos de História do Direito. 2 ed. Belo Horizonte: Del Rey, 2003.

WOLKMER, Antonio Carlos. História do Direito no Brasil. Rio de Janeiro: Forense, 1998. Introdução ao pensamento jurídico crítico. São Paulo: Acadêmica, 1995.

Trabalho enviado em 16 de maio de 2018

Aceito em 03 de setembro de 2018 